\title{
Fauna activity on soils developing on dead logs in an ancient inland temperate rainforest of North British Columbia (Canada)
}

\author{
Beata Klimek ${ }^{1} \cdot$ Maria Niklińska $^{1}$ \\ Received: 26 September 2019 / Accepted: 30 December 2019 / Published online: 18 January 2020 \\ (C) The Author(s) 2020
}

\begin{abstract}
Purpose The aim of the study was to compare the feeding activity of soil fauna in forest floor soil and in soil layer developing on dead cedar logs in temperate ancient rainforest of North British Columbia (Canada) inlands.

Materials and methods Bait-lamina test was applied to study the soil fauna feeding activity. On each of ten plots, measurements were conducted on a dead tree trunk $(\log )$ and in the typical forest floor soil in the close vicinity $(<10 \mathrm{~m})$ of the log. A range of physicochemical properties of soil was measured for both environments.

Results and discussion The feeding activity of soil fauna did not differ between log and forest floor soils (paired $t$ test, $t=0.1693$ ). Log soils and forest floor soils did not differ in a range of physicochemical properties measured, that is element content and $\mathrm{pH}$, with the exception of organic matter content, which was significantly higher in log soil than in forest floor soil ( $p=0.037)$.

Conclusions Soil developing on dead cedar logs creates a similar environment for the development and activity of soil fauna as the organic layer of forest floor soil.
\end{abstract}

Keywords Bait-lamina strips $\cdot$ Soil fauna feeding activity $\cdot$ Forest soils $\cdot$ Dead wood

\section{Introduction}

Soil development is an extremely long-standing process. Environmental characteristics, such as temperature, precipitation, bedrock and vegetation cover, affect strongly pedogenesis ratio and final physicochemical and biological soil characteristics. Soils are crucial element of terrestrial ecosystem functioning, where energy flow and element cycling take place. The falling trees generate long-term spatial patterns in soil physicochemical properties and maintain microsite heterogeneity in forest communities (Beatty and Stone 1986). Fallen tree trunks, called here logs, relatively rarely provide such good support for the organic soil layer forming on them. Organic matter layering is limited on their surface of roundshaped across, especially on small logs. Inland temperate

Responsible editor: Arnaud Temme

Beata Klimek

beata.klimek@uj.edu.pl

1 Institute of Environmental Sciences, Faculty of Biology, Jagiellonian University, Gronostajowa 7, 30-387 Kraków, Poland rainforests dominated by old western red cedar (Thuja plicata Donn) and western hemlock (Tsuga heterophylla (Raf.) Sarg.) occurring in wet and very wet cool parts of interior British Columbia (BC) in Canada are locally rich in dead trees logs which are large and old enough to initiate soil development processes (Arsenaut and Goward 2000; Matsuzaki et al. 2013). These long-standing tree species (>1200 y) have trunks which can reach a 6-m diameter at the base and extends upward for $60 \mathrm{~m}$ (Waring and Franklin 1979). Giant dead logs can achieve $2000 \mathrm{y}$, and organic matter layer on their surface can reach up to $15-\mathrm{cm}$ thickness. Ancient cedar stands within BC's inlands represent a globally unique ecosystem (Waring and Franklin 1979; Stevenson et al. 2011; Coxson et al. 2012).

We goaled here to estimate fauna activity in layer developing on cedar logs and compare it with fauna activity in regular soil organic layer. Soil fauna which facilitates the microbial attack on soil organic matter directly by the consumption and fragmentation of SOM and indirectly by their influence on microbial activity, biomass and community composition (Cortet et al. 1999; Bonkowski et al. 2000; Rożen et al. 2010) plays an important role in soil processes. Soil fauna is influenced by a variety of environmental factors, such as local climatic conditions, edaphic characteristics, vegetation and anthropogenic factors (Rożen et al. 2010). These factors 
may result in diversified activity and taxonomic composition of soil fauna community in different forest ecosystems; thus, soil fauna can be treated as indicators of soil health and fertility. For certain research applications, arduously counting and identifying numerous small and soft-body animal species that can be found in the soil is not necessary. For some research, a general assessment of field fauna activity is a sufficient indicator of ecological processes running on particular environment (Rożen et al. 2010).

The method used in our study to assess soil fauna field activity was a common method of measuring the activity of soil fauna, the bait-lamina strips test. This particular method was first described by Von Törne (1990). The bait-lamina method allows the assessment of the feeding activity of soil fauna with negligible effects from soil microorganisms and abiotic decay (Helling et al. 1998; Hamel et al. 2007). Bait can be composed of different ingredients but should be an attractive food for various groups of soil mesofauna. This can be achieved by adding pulverised nettle leaves, which are rich in protein (Helling et al. 1998). The extraordinary simplicity and low cost of the bait-lamina method explain why this approach is widely used to study the activity of soil fauna in various applications, for example detecting the effects of soil pollution (Reinecke et al. 2002; André et al. 2009), vegetation diversity (Hamel et al. 2007), agrotechnical or recultivation treatments (Hohberg et al. 2001; Jacometti et al. 2007) or altitudinal climatic gradient (Niklińska and Klimek 2011). Lately, Klimek et al. (2015) used this method to compare soil fauna activity in various types of temperate forests.

The aim of our study was to compare soil fauna activity between two different environments, organic layer developed on dead logs of western cedar and in soil of forest floor. It was expected that logs offer a similar environment as forest floor for small soil fauna. Another goal was to check if any of the physicochemical properties of soil affect fauna feeding activity in these ancient forests.

\section{Materials and methods}

\subsection{Study area}

British Columbia (BC)'s inland temperate rainforests are located in the Rocky Mountains, within watershed of the upper Fraser River, in valley bottom to mid-slope positions on the windward slope. Climatic data for studied area were taken from the Ancient Forest Historical Data Set - estimated by ClimateWNA version 6.00 (Wang et al. 2012). Based on that, in years 1961-1990 in September, the mean air temperature was $9.1{ }^{\circ} \mathrm{C}$ and the total precipitation was $86 \mathrm{~mm}$. In September of 2013, when the current study was performed, it was rather warm and dry comparing with the available historical data: the mean air temperature was $11.4{ }^{\circ} \mathrm{C}$ and total precipitation was $26.3 \mathrm{~mm}$. Specifically, during the field experiment duration in the second half of the month, the air temperatures did not fall below $0{ }^{\circ} \mathrm{C}$; the lowest temperature measured was $3.2{ }^{\circ} \mathrm{C}$ and the highest temperature measured was $25.8^{\circ} \mathrm{C}$ with a mean temperature of $10.8^{\circ} \mathrm{C}$ and sum of the precipitation of $17.6 \mathrm{~mm}$. The climatic conditions are a result of the same prevailing weather systems and precipitation that nourish coastal rainforests creating a secondary zone of high precipitation as they cross interior mountain ranges. Also, meltwater from the winter snowpack maintains groundwater supplies and creates conditions of high stand humidity during the summer period, preventing them of fires.

Canopy structure in ancient cedar stands is quite open, with gaps often formed by small seepage areas and springs (Radies et al. 2009). Ancient cedar stands often support a dense understorey, with devil's club (Oplopanax horridus) 2-3 m in height and lush lady fern (Athyrium filix-femina) and skunk cabbage (Lysichiton americanus) in wet seepage areas (Coxson et al. 2012). Well-illuminated branches and humid microclimate are a major factor in the development of rich canopy lichen communities (Coxson et al. 2012). The current study was performed along the Ancient Forest Trail (starting point $53^{\circ} 45^{\prime} 47.7^{\prime \prime} \mathrm{N} 121^{\circ} 13^{\prime} 07.3^{\prime \prime} \mathrm{W}$ at elevation $800 \mathrm{~m}$ a.s.1.), located $115 \mathrm{~km}$ east of the city of Prince George. Ancient Forest Trail is a loop of $2.3 \mathrm{~km}$ long and of elevation gain $250 \mathrm{~m}$. The study was performed in September 2013, before the protected area was established there (2016).

\subsection{Bait-lamina field test and soil sampling}

On each of ten plots, soil fauna activity was measured on dead tree trunk $(\log )$ and in the forest floor soil in the close log vicinity $(<10 \mathrm{~m})$. Selected logs surfaces were available for people without using ladders or other equipment. Baitlamina plastic strips of $120 \mathrm{~mm} \times 6 \mathrm{~mm} \times 1 \mathrm{~mm}$ were cut down at one end, which facilitate placing them into soil. A homogenous substrate was composed of cellulose (SigmaAldrich), agar (Becton, Dickinson Co.) and pulverised, dried nettle leaves (Herbapol, Poland) (1:1:1, w/w/w). Strips were filled with bait of the consistence of paste 1 day before they were placed into the soil. Openings were filled manually, with controlled precision of the work under the light. Strips were placed on linear transects of $3 \mathrm{~m}$ in length (15 strips every $20 \mathrm{~cm}$ ). To perform a bait-lamina test, 300 strips were used. Strips were exposed in the soil for 10 days. Immediately after collection, the perforated apertures in the strips were checked and noted. The feeding activity of soil fauna was expressed as a $\%$ of the perforated apertures in the entire strip set per each site.

During strips collection, the soil samples from the upper 10-cm layer were collected to determine detailed physicochemical characteristics. One mixed soil sample was collected 
per research site. Each soil sample consisted of three subsamples collected along bait-lamina strips line, mixed to obtain one representative sample. Altogether, 20 mixed soil samples were collected, 10 from logs and 10 from forest floor soil. Directly after collection, the samples were handy sorted to remove the green parts of plants, stones and roots, packed into plastic sacks and transported to the laboratory field-moist. The soil was stored at $4{ }^{\circ} \mathrm{C}$.

\subsection{Soil physicochemical laboratory analysis}

The dry weights (DW) of the soil samples were determined by drying them at $105^{\circ} \mathrm{C}$ for $24 \mathrm{~h}$. Next, the organic matter content $(\mathrm{OM})$ in dry weight was determined as the loss on ignition at $550{ }^{\circ} \mathrm{C}$ for $24 \mathrm{~h}$. The water holding capacity (WHC) was measured by a standard gravimetric method. The soil $\mathrm{pH}$ was measured in air-dried subsamples $(2 \mathrm{~g})$ shaken in distilled water $(1: 10 \mathrm{w} / \mathrm{v})$ for $1 \mathrm{~h}$ at $200 \mathrm{rpm}$. The organic $\mathrm{C}$, total $\mathrm{N}$ and total $\mathrm{S}$ were analysed by dry combustion with an elemental analyser (Vario El III, Elementar Analysensysteme $\mathrm{GmbH}$ ). The total concentrations of elements $(\mathrm{Ca}, \mathrm{Mg}, \mathrm{K}, \mathrm{P})$ were determined in each soil sample after wet digestion of $0.3 \mathrm{~g}$ of DW in $5 \mathrm{ml}$ mixture of suprapure concentrated $\mathrm{HNO}_{3}$ and $\mathrm{HClO}_{4}(5: 1 \mathrm{v} / \mathrm{v}$ ) (SigmaAldrich). The concentrations of the metals in the digests were measured using atomic absorption spectrometry (AAS) with flame or a graphite furnace nebuliser (Perkin-Elmer), and the $\mathrm{P}$ concentration was measured on the flow-injection analyser (FIA compact, MLE). To check the accuracy of the method, four blank samples and three replicates of a standard certified material (Trace elements Pine needles 1575a NIST® SRM®) were analysed with the samples. Each sample was analysed in two replicates from every soil sample and averaged. The bait substrate was analysed together with the soil samples in five replicates for the elements' concentrations.

\subsection{Statistical analysis}

The normality criterion for the data distribution within groups was checked with the Shapiro-Wilk test and transformed if needed. Differences in the mean soil fauna feeding activity ( $\%$ of apertures perforation per day) between the logs and forest floor were compared with paired $t$ test. The results were considered significantly different at $p<0.05$. A paired $t$ test was run also to test the differences in soil chemical and physical properties between the soils from logs and forest floor.

To assess the simultaneous effect of various site characteristics on the feeding activity of soil fauna, a multiple regression was used with independent variables chosen based on a multiple-variable analysis. Next, the physicochemical characteristics of the soil were subjected to a principal component analysis to reduce the number of variables, and a multiple regression was performed to determine the relationship between the activity of soil fauna and the main principal components (PCs).

All statistical analyses were carried out using Statgraphics 18 (StatPoint Technologies, Inc., Warrenton, VA, USA).

\section{Results}

The mean activity of soil fauna in all studied sites altogether varied from 2.3 to $9.3 \%$ of apertures perforation per exposition day with a mean value of $6 \%$ per day. This confirms that exposition duration was adequately long. There was no difference in the feeding activity of soil fauna between $\operatorname{logs}(5.6 \%)$ and forest floor soil (6.4\%) $(t=0.1693)$ (Fig. 1).

Collected soil samples were characterised by high field moisture (dry mass range of $14-42 \%$ ) and high organic matter content (range of $67-94 \%$ of dry mass) (Table 1). The samples collected from logs and forest floor differed in organic matter content and was higher in logs than in forest floor $(t=0.0307)$ (Table 1). The other soil physicochemical properties measured did not differ significantly between logs and forest floor (Table 1). Both soils were acidic with a mean value of $\mathrm{pH} 4.90$ (Table 1). The bait substrate element composition (mean values) were as follows: $\mathrm{C}, 35.49 \% ; \mathrm{N}, 1.50 \%$; $\mathrm{P}, 0.35 \%$ and $\mathrm{S}, 0.41 \%$ of dry weight of soil. The total content of other essential chemical elements in the bait substrate were as follows: $\mathrm{Ca}, 2.49 \%$; $\mathrm{Mg}, 0.17 \%$ and $\mathrm{K}, 1.13 \%$ of dry weight.

A multiple-variable analysis indicated that soil parameters were highly correlated (data not shown). Only three independent variables could be used in the multiple regression: the organic matter content as a measure of carbon sequestration and decomposition rate and strongly positively correlated with such elements as carbon, nitrogen and sulphur; the soil $\mathrm{pH}$ as a measure of the soil acidity which was negatively well correlated with potassium and calcium concentration as a proxy of the content of macro elements (well correlated with phosphorus and manganese). The model for these three factors was not significant $(p=0.8423)$ and all tested factors were not

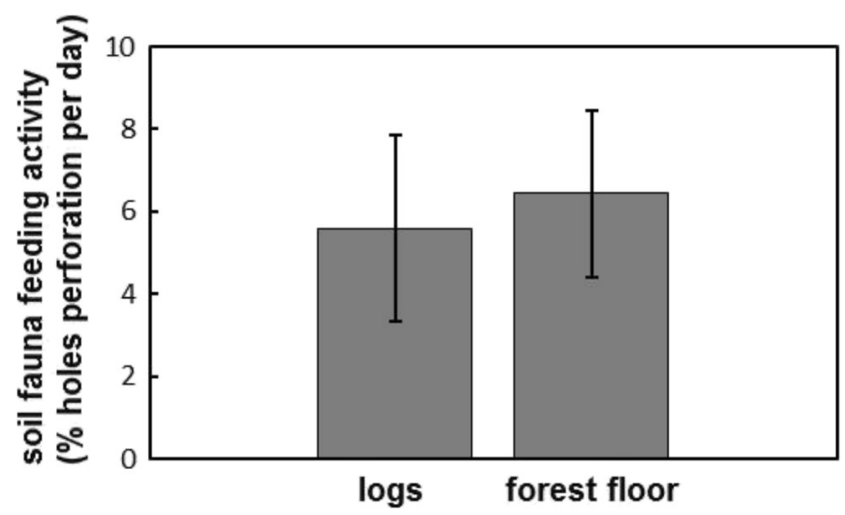

Fig. 1 Soil fauna feeding activity in soils on logs and forest floor 
significant, even when the backward and forward factors selection was run.

The principal component analysis (PCA) reduced the number of variables and allowed these variables to be tested as to their possible effects on the feeding activity of soil fauna. Three PCs explained subsequently $32 \%, 25 \%$ and $16 \%$ of the variability in the data (Fig. 2). The first PC was based on organic matter content, water holding capacity and N, P and S concentration and was a compilation of information on soil organic matter content and fertility. The second PC was composed of the $\mathrm{pH}, \mathrm{C}, \mathrm{S}$ and $\mathrm{K}$ content, and the third one was based on the $\mathrm{Ca}$ and $\mathrm{Mg}$ content. There was not, however, a significant relationship between the PCs and the feeding activity of soil fauna $(p=0.7923)$.

\section{Discussion}

We showed that soil fauna feeding activity in ancient west cedar stands of North British Columbia was similar on logs and in forest floor soil. Giant cedar stands (and logs) are found on specific topographic positions because wet environment allows them for undisturbed growth during summer and specifically protect trees from fires during dry periods. Giant logs of red cedar allow for organic matter garnering for up to hundreds of years, specifically, extremely wet microclimate which prevents cumulated organic matter on logs from desiccation. The studied area is characterised by a high precipitation level (Wang et al. 2012). However, the abovementioned wet microclimate is also responsible for abundant springs, groundwater runoff and seepages (Coxson et al. 2012). Some of the springs form waterfalls, which foster water dispersion into air and allow to create wet fog which in turn favourable for soil moisture content effective buffering from changes in precipitation. Soil dry mass measured at the end of the experiment was similar on logs and in ground soil. The studies on soil fauna feeding activity on logs in ancient west cedar stands could be

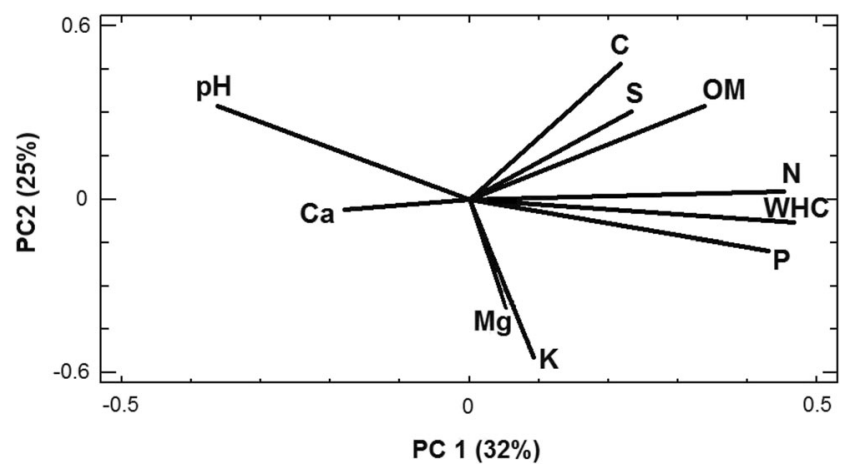

Fig. 2 Interdependencies between the physical and chemical properties of the soil (results of PCA analysis). The first and second components are presented. All soil data used in the PCA analysis are presented in Table 1 (means and their standard deviations) 
expanded by measurements in different periods of the year, especially during summer.

Therefore, these combined factors - presence of big logs and wet microclimate - cause that ancient inland rainforest to create of extra space of living for soil fauna. The mean activity of soil fauna in studied region was high, that is $6 \%$ of apertures perforation per experiment day, comparing other studies using application of bait-lamina method. For example, Klimek et al. (2015) found mean activity of soil fauna in forest floor soils of seven types of temperate forests ranged from 1.5 to $2.8 \%$ of apertures perforation per experiment day (during 12 days exposition), that is half of the result of the current study. Another study in temperate forests along short altitudinal mountain gradient in Carpathians found even smaller values for bait-lamina test: $0.2-2.4 \%$ per day (during 32-day exposition) (Niklińska and Klimek 2011). The values obtained in ancient west cedar stands of North British Columbia were up-close to values obtained for Amazonia rainforests. Römbke et al. (2006) studying feeding activities of soil fauna in Amazonia found a high fauna activity at $6.8-17.5 \%$ per day (in 4 days exposition).

High soil fauna feeding activity may be driven by different factors and resulted both from environmental and biological drivers. Overall fauna density as well as community composition may affect ratio of bite consumption (Helling et al. 1998; Rożen 2010). In a laboratory experiment, Helling et al. (1998) showed that feeding activity was correlated best with enchytraeid density. The enchytraeids (Oligochaeta) are the key mesofauna species in northern and coniferous temperate forest (Laakso and Setala 1999; Briones et al. 2004). Enchytraeids are mainly restricted to moist habitats (Abrahamsen 1971) and prefer slightly acid to neutral conditions, under which their diversity is the greatest (Jänsch et al. 2005). Battigelli et al. (1994) who studied mixed red cedarwestern hemlock forest stands in British Columbia found the highest number of individuals of nematodes comparing with other groups of soil invertebrates, with the highest relative biomass for diplopoda and enchytraeid groups. Massive litter production support high ratio of soil development processes and high soil biological activity. However, in temperate region, slower decomposition is observed during cold season. Low winter temperatures are largely responsible for organic matter accumulation in temperate rainforests. Matsuzaki et al. (2013) found that a major difference in soils of temperate and tropical rainforest is the storage of SOC.

\section{Conclusions}

Soil carbon storage is greatest in unmanaged forests (Williams and Powers 2019). Also, soil fauna diversity, especially enchytraeids, is greater in unmanaged forest compared with the strongly managed (Boros et al. 2019).
Forestry is one of the traditional industries in the upper Fraser area; fortunately, cedar timber is regarded as a low-value timber and at least some cedar stands were left behind during big-scale tree harvesting (Coxson et al. 2012). It was showed that unmanaged, ancient forests throughout the world are hot spots for diversity of various groups of organisms, for example, canopy macrolichen (Radies et al. 2009), soil microbial community (Gömöryová et al. 2013), arthropods (Schowalter 2017) or small mammals (Sullivan et al. 2001). Therefore, we can expect for high soil fauna diversity in ancient temperate rainforests, both in forest floor and log soils. These suggest for further direction of the research, as to our knowledge, no data on the soil fauna diversity and composition are available for that area.

Composition and diversity of small fauna differ strongly between niches offered by forest stands. For example, Lindo and Stevenson (2007) who studied microathropod abundance in the British Columbia red cedar stands found lower abundance of microarthropods in canopy litter (collected on trees, on height above $25 \mathrm{~m}$ ) than in soil. Moreover, they found that microarthropod assemblage composition differed significantly between canopy litter and soil (Lindo and Stevenson 2007). In a current study, the distinct fauna composition could be expected also between soil and logs. On the other hand, logs were located close to the ground which supports their colonisation much easily and they were last in more humid microclimate compared with high trees canopy. Another thing is dead versus living tree-they offer completely different conditions for small fauna. Therefore, we expect that fauna assemblage composition on dead long-standing logs may be similar to these in soils in their close vicinity.

Acknowledgements The authors wish to thank Prof. Darwyn Coxson for presenting fascinating Ancient Forest Trail and his valuable assistance in field work as well as to Professor Stephen Dery, whose lab maintains the climate station at the Ancient Forest trail, who provided climatic data.

Funding information This study was supported by a grant 'ECOLOGY' from the European Union Seventh Programme (UDA-POKL04.01.0100-053/09-00) and by Jagiellonian University funds (subsidy DS/ WBiNoZ/INoS/758 in 2013).

Open Access This article is licensed under a Creative Commons Attribution 4.0 International License, which permits use, sharing, adaptation, distribution and reproduction in any medium or format, as long as you give appropriate credit to the original author(s) and the source, provide a link to the Creative Commons licence, and indicate if changes were made. The images or other third party material in this article are included in the article's Creative Commons licence, unless indicated otherwise in a credit line to the material. If material is not included in the article's Creative Commons licence and your intended use is not permitted by statutory regulation or exceeds the permitted use, you will need to obtain permission directly from the copyright holder. To view a copy of this licence, visit http://creativecommons.org/licenses/by/4.0/. 


\section{References}

Abrahamsen G (1971) The influence of temperature and soil moisture on the population density of Cognettia sphagnetorum (Oligochaeta: Enchytraeidae) in cultures with homogenized raw humus. Pedobiologia 11:417-424

André A, Antunes SC, Gonçalves F, Pereira R (2009) Bait-lamina assay as a tool to assess the effects of metal contamination in the feeding activity of soil invertebrates within a uranium mine area. Environ Pollut 157:2368-2377

Arsenaut A, Goward T (2000) Ecological characteristics of inland rain forests. Proceedings of a Conference on the Biology and Management of Species and Habitats at Risk, Kamloops, B.C., 15-19 Feb.,1999

Battigelli JP, Berch SM, Mashall VG (1994) Soil fauna communities in two distinct but adjacent forest types on northern Vancouver Island, British Columbia. Can J For Res 24:1557-1566

Beatty SW, Stone LE (1986) The variety of soil microsites created by tree falls. Can J For Res 16:539-548

Bonkowski M, Cheng W, Griffiths BS, Alphei J, Scheu S (2000) Microbial-faunal interaction in the rhizosphere and effects on plant growth. Eur J Soil Biol 36:135-147

Briones MJI, Poskitt J, Ostle N (2004) Influence of warming and enchytraeid activities on soil $\mathrm{CO} 2$ and $\mathrm{CH} 4$ fluxes. Soil Biol Biochem 36(11):1851-1859

Boros G, Kovács B, Ódor P (2019) Green tree retention enhances negative short-term effects of clear-cutting on enchytraeid assemblages in a temperate forest. Appl Soil Ecol 136:106-115

Cortet J, Gomot-De Vauflery A, Poinsot-Balaguer N, Gomot L, Texier C, Cluzeau D (1999) The use of invertebrate soil fauna in monitoring pollution effects. Eur J Soil Biol 35:115-134

Coxson D, Connel D, Goward T (2012) Analysis of ancient western redcedar stands in the upper Fraser River watershed and scenarios for protection. J Ecosys Manag 13:1-20

Gömöryová E, Ujházy K, Martinák M, Gömöry D (2013) Soil microbial community response to variation in vegetation and abiotic environment in a temperate old-growth forest. Appl Soil Ecol 68:10-19

Hamel C, Schellenberg MP, Hanson K, Wang H (2007) Evaluation of the 'bait-lamina test' to assess soil microfauna feeding activity in mixed grassland. Appl Soil Ecol 36:199-204

Helling B, Pfeiff G, Larink O (1998) A comparison of feeding activity of collembolan and enchytraeid in laboratory studies using the baitlamina test. Appl Soil Ecol 7:207-212

Hohberg K, Schulz H-J, Schwalbe T, Seifert B, Vogel J, Voigtländer K, Zimdars B, Zulka KP (2001) Development of soil fauna at mine sites during 46 years after afforestation. Pedobiologia 45:243-271

Jacometti MA, Wratten SD, Walter M (2007) Understorey management increases grape quality, yield and resistance to Botrytis cinerea. Agric Ecosyst Environ 22:349-356
Klimek B, Niklińska M, Jaźwa M, Chodak M, Tarasek A (2015) Application of the bait-lamina method to measure the feeding activity of soil Fauna in temperate forests. Pol J Ecol 63(3):414-423

Laakso J, Setala H (1999) Sensitivity of primary production to changes in the architecture of belowground food webs. Oikos 87(1):57

Lindo Z, Stevenson S (2007) Diversity and distribution of Oribatid mites (Acari: Oribatida) associated with arboreal and terrestrial habitats in interior cedar-hemlock forests, British Columbia, Canada. Northwest Sci 81:305-315

Matsuzaki E, Sanborn P, Fredeen AL, Shaw CH, Hawkins C (2013) Carbon stocks in managed and unmanaged old-growth western red cedar and western hemlock stands of Canada's inland temperate rainforests. Forest Ecol Manag 297:108-119

Niklińska M, Klimek B (2011) Dynamics and stratification of soil biota activity along an altitudinal climatic gradient in West Carpathians. J Biol Res-Thessaloniki 16:177-187

Radies D, Coxson D, Johnson C, Konwicki K (2009) Predicting canopy macrolichen diversity and abundance within old-growth inland temperate rainforests. For Ecol Manag 259:86-97

Reinecke AJ, Helling B, Louw K, Fourie J, Reinecke SA (2002) The impact of different herbicides and cover crops on soil biological activity in vineyards in the Western cape, South Africa. Pedobiologia 46(5):475-484

Römbke JR, Höfer H, Garcia MVB, Martius C (2006) Feeding activities of soil organisms at four different forest sites in Central Amazonia using the bait lamina method. J Trop Ecol 22:313-320

Rożen A, Sobczyk $Ł$, Liszka K, Weiner J (2010) Soil faunal activity as measured by the bait-lamina test in monocultures of 14 tree species in the Siemianice common-garden experiment, Poland. Appl Soil Ecol 45:160-167

Schowalter T (2017) Arthropod diversity and functional importance in old-growth forests of North America. Forests 8:97-110

Stevenson S, Armleder H, Arsenault A, Coxson D, DeLong C, Jull M (2011) British Columbia's inland rainforest: ecology, conservation and management. UBC Press, Vancouver

Sullivan TP, Sullivan DS, Lindgren PMF (2001) Stand structure and small mammals in young lodgepole pine forest: 10-year results after thinning. Ecol Appl 11:1151-1173

von Törne E (1990) Assessing feeding activities of soil-living animals. I Bait-lamina-tests - Pedobiol 34:89-101

Wang T, Hamann A, Spittlehouse D, Murdock TN (2012) ClimateWNA - high-resolution spatial climate data for western North America. J Appl Meteorol Climatol 61:16-29

Williams NG, Powers MD (2019) Carbon storage implications of active management in mature Pseudotsuga menziesii forests of western Oregon. Forest Ecol Manag 432:761-775

Waring RH, Franklin JF (1979) Evergreen coniferous forests of the Pacific northwest. Science 204(4400):1380-1386

Publisher's note Springer Nature remains neutral with regard to jurisdictional claims in published maps and institutional affiliations. 